\title{
落下水膜に生じる自励振動のメカニズムに関する研究*
}

\author{
森 博輝 ${ }^{* 1}$, 長嶺 拓夫 ${ }^{* 1}$, 伊東 亮 $^{* 2}$, 佐藤 勇一 ${ }^{* 3}$
}

\section{Mechanism of Self-Excited Vibration of a Falling Water Sheet}

\author{
Hiroki MORI ${ }^{*}$, Takuo NAGAMINE \\ Ryo ITO and Yuichi SATO \\ ${ }^{* 1}$ Department of Mechanical Engineering, Saitama University, \\ 255 Shimo-Okubo, Sakura-ku, Saitama-shi, Saitama, 338-8570 Japan
}

This paper describes experimental and analytical study on the behavior of a falling water sheet. The observation of water sheet displacement and air pressure variation in the chamber implies that one of the causes of oscillation is downward squeeze action of a water sheet on an air chamber. We propose a simplified analytical model. Analytical results agree well with experimental ones. Further analytical results explain the occurrence of multiple modes of oscillation in a condition. In addition, we explain the instability mechanism using the work done by a falling water sheet on an enclosed chamber.

Key Words : Self-Excited Vibration, Stability, Dynamics, Falling Water Sheet, Nappe Oscillation, Air Chamber

\section{1. 緒言}

砂防ダムのような固定堰，あるいは取水堰のような可動堰から越流により水が膜状になって落下する場合，し ばしば水膜振動が起こる．これにより民家の空ガラスを振動させたり，ゲートそのものを振動させたりして問題 となることがある。この現象はこれまで，水膜自身の不安定性，水膜背後の空気圧力の変動，午一ト自体が振動 系と見なせる場合の 3 つ要因に基づくと考えられている.

空気中に噴出された液体の挙動は 19 世紀頃から研究されている(1),(2). 1953 年に Squire や York は主に液膜と空 気の慣性力やせん断力の不均一に起因する流体力学的不安定性に着目し，空気中を移動する液体の不規則な挙動 やばらけを検討し，液膜は空気中の移動速度が大きいほど不安定で，表面張力が大きいほど安定になり，また移 動速度と表面張力によって，不安定化する振動数の上限と最も発生し易い振動数が決まることを明らかにした (3),(4). その後 Hagarty ら ${ }^{(5)}$ によって液膜の不安定にはサイナスモードとディレイショナルモードが存在することな どがわかり，さらに数值計算を利用して粘性や重力を付加した解析も行われている(6) (9).

堰から落下する水膜振動に関する研究も 1940 年頃からなされ, 水膜と堰との間の空気圧力の変動がひとつの要 因となっていると報告されている(10). 1964 年, Schwartz ${ }^{(11)}$ は実験を行い閉空間内部の周期的圧力变動が最も水膜 の振動にエネルギーを与えるという条件を定性的に考察し，水が堰を落下する時間 $\times$ 発生振動数 $=K+\delta(K=1$, $2,3, \cdots, \delta=1 / 4)$ となるとの結果を導いた，その後，Treiber ${ }^{(12)}$ が堰の越流による水膜の解析を行い，Kolkman ${ }^{(13)}$ は 背面に閉空間を有する鉛直落下水膜の挙動に及ぼす閉空間の影響を検討した．大久保ら ${ }^{(14)}$ は，同様の系で実験を 行い, 観察されたいくつかの振動数のうち, 一番高いものは, 流体力学的不安定性による振動数に近い值と報告 している. Casperson ${ }^{(15)}$ と京藤 ${ }^{(16)}$ はその流体力学的不安定性の影響を考慮に入れ解析を行った.

\footnotetext{
*原稿受付 2012 年 4 月 9 日

*1 正員, 埼玉大学 大学院理工学研究科（テ338-8570 埼玉県さいたま市桜下大久保 255 )

*2 埼玉大学 大学院理工学研究科

*3 正員, フェロー, 埼玉大学 大学院理工学研究科

E-mail: hmori@mech.saitama-u.ac.jp
} 
他方，ゲート自体が振動系とみなせる要素をもつフラップゲートなどが絡んだ振動に関する研究も進められて いる(17) (20).

固定堰などでみられる水膜振動は水膜背後空間の圧力変動が支配的なナップ(Nappe)振動と考えられる. 本報で は，振動発生メカニズムを明らかにするため，まず水膜変位と水膜背後圧力の関係を 2 つの実験装置を用いて計 測した. 実験結果を基に水膜変位と水膜背後圧力が相互作用をもつ簡単な解析モデルを提案している. 実験にお いて，1つの条件下で 2 つから 3 つの複数のモードの水膜振動が現れるが，その中のどのモードが現れやすいか についてもメカニズムは今まで十分に明らかにされていなかった．提案するモデルを用いた解析結果は，その選 択のメカニズムを定性的に説明するとともに実験結果をよく説明できる．また，水膜がなす仕事についても考察 を行ったので報告する.

\section{2. 主 な 記 号}

$a, a_{N}:$ 水膜の厚さ, 上部水槽のスリット幅

$u, u_{N}:$ 水膜の $x$ 方向(鉛直方向)の速度，上部水槽から放出される水膜の初速度

$v \quad$ : 水膜の $y$ 方向(水膜厚さ方向)の速度

$\eta \quad:$ 水膜の $x$ 軸からの微小変位

$\Delta p:$ : 大気圧 $p_{0}$ からの閉空間内の微小変動圧力

$\omega=2 \pi f:$ 閉空間内圧力変動の角振動数

$h \quad$ : 落下高さ

$\rho_{w}:$ 水の密度

$T \quad$ : スリット出口から水面までの落下時間

$S: T \times f=($ 落下時間 $\times$ 振動数 $)$

\section{3. 実験}

図 1 に実験装置概略図を示す. 上部水槽底に開けられた幅 $a_{N}(1.3$ または $3.1 \mathrm{~mm})$, 長さ $300 \mathrm{~mm}$ のスリットか ら水が下部水槽へ落下寸る. 落下寸る水が完全な水膜を形成するように図 1(a)に示寸スリットの前後に $300 \mathrm{~mm}$ 離して透明なアクリル板（側板）を垂直に設置した. さらに，スリットと平行に $b(300,200,95 \mathrm{~mm} の 3$ 種類)だ け離して背面板を垂直に設けた．水膜，側板，背面板および下部水槽内の水によって，閉空間が形成される．実 際には側板，背面板と上部水槽底との間にはわずかなすき間が存在しているが，以下では簡単のため閉空間と表 現する，一般に落下寸る水膜の速度が高くなると，水膜は振動を始める．水量が不足して水膜が途中で大きく破 れているときは振動は発生しにくい.

図 1(b)に示寸ように上部水槽からスリットを通って水が滑らかに落下寸るように 2 枚の板をノズルとして取り 付けた. 上部水槽内の水位 $d$ (上部水面からスリット出口までの距離)は $150,200,250 \mathrm{~mm}$ とし, 下部水槽の水をポ ンプで上部水槽へ汲み上げ，実験中は同一の水位を保った，スリットとの間に整流板を置いた，下部水槽の水位 を変化させることにより, 落下高さ $h$ を $470 \sim 620 \mathrm{~mm}$ の範囲で変えた. ただし, 実験中は水膜が振動するため下 部夜面は波立っており，真の落下距離とは少し異なるが，液面に整流板を置き，波立たないようにしても，水膜 振動の発生に関しては殆ど影響は無かった. 水膜振動の様子を高速度カメラ $(30 \sim 500 \mathrm{fps}) て ゙$ 撮影し, 各条件におけ る発生振動数などを調べた。 また，閉空間内の圧力変動も測定した.

振動発生直後は複数のモードが混在した状態になることもあるが，短時間(2～5 秒程度)でいずれか 1 つのモー ドに落ち着いた。

図 2 は，水膜最下部の変位および閉空間の圧力と，水膜変位を時間に対して示したもので，閉空間は水膜の右 側である. 水膜変位の正の向きは $y$ 軸の正の向きである (図 1 参照). 図 2(a)および2(b)はそれぞれ, 水膜振動が 成長しているときおよび完全に成長したときの測定結果である. 図2(a)および2(b)いずれの場合も, 閉空間の圧 力変化は水膜最下部の変位と同位相，つまり水膜最下部の変位が前方に最大となるとき閉空間の圧力は最大とな 


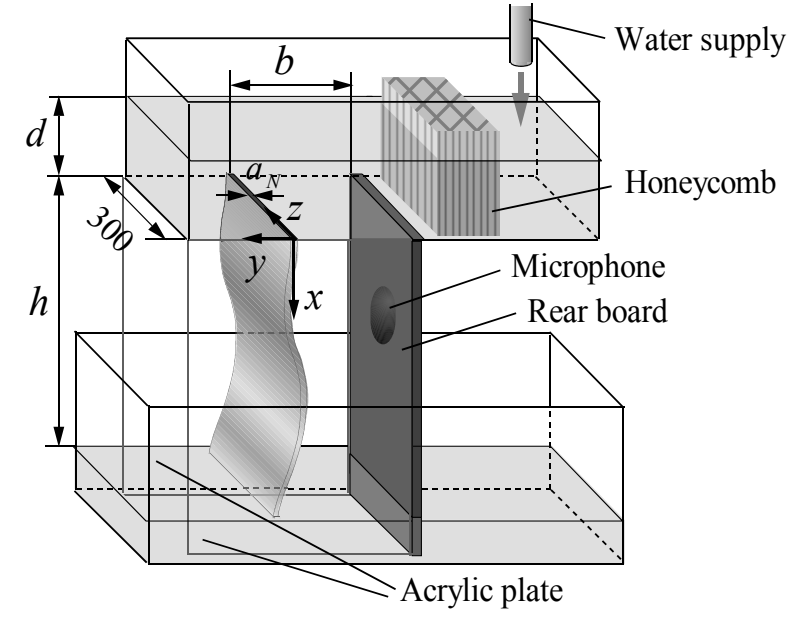

(a) Overview

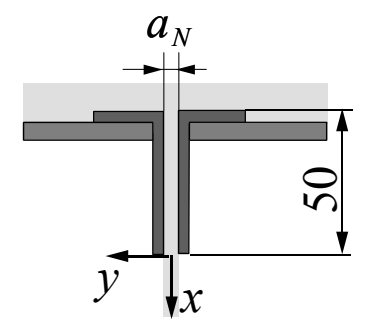

(b) Water outlet from the upper reservoir

Fig.1 Experimental apparatus

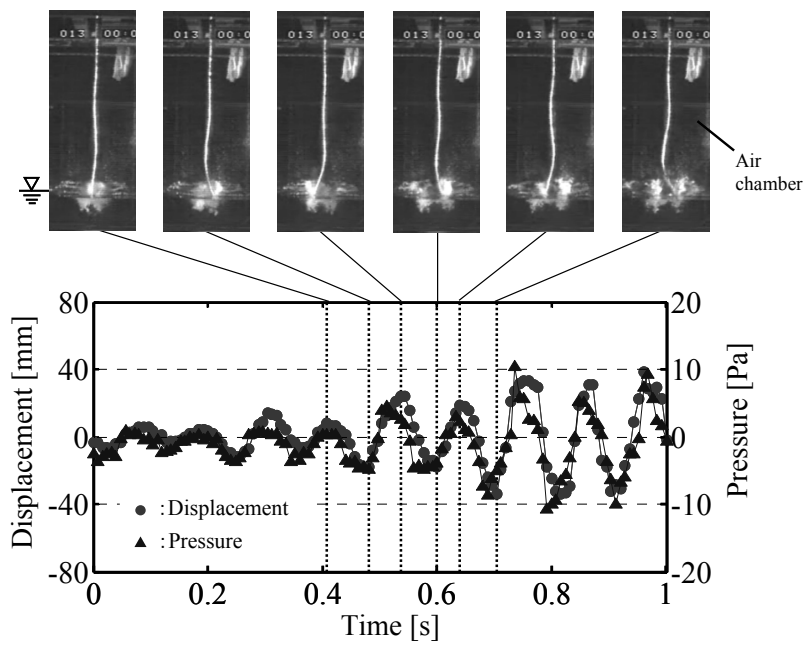

(a) Onset of oscillation

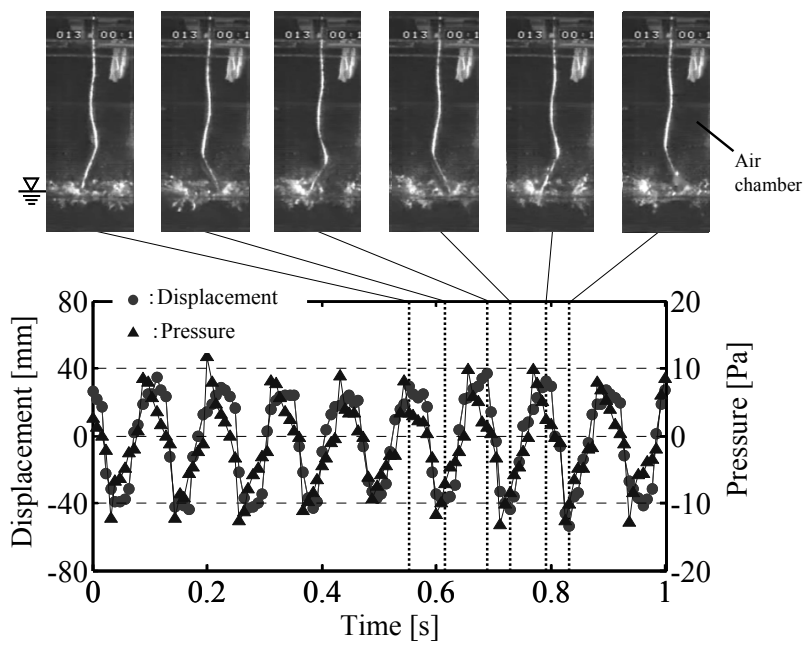

(b) Fully developed oscillation

Fig.2 The relation between the pressure variation in the air chamber and the bottom displacement of a water sheet ( $a_{N}=1.3 \mathrm{~mm}, b=300 \mathrm{~mm}, d=150 \mathrm{~mm}, h=520 \mathrm{~mm}, f=8.9 \mathrm{~Hz}, n=2$ )

つていることがわかる. 落下水膜に含まれる波の数を $n$ で表し, $n$ 次モードと呼ぶことにすると, 図 2 に示す振 動は 2 次の振動モード $(n=2)$ である.

上部水槽のスリット出口から落下する水膜の初速度 $u_{N}$ は, スリットから流れ出る流量 $Q$ を測定し, スリット 出口の断面積 $A$ との関係式

$$
A u_{N}=Q
$$

から求めた. 水深 $d$ と $u_{N}$ との関係は流量係数を $C$ として

$$
u_{N}=C \sqrt{2 g d}
$$

となる. 流量係数 $C$ は $a_{N}=3.1 \mathrm{~mm}$ のき $C=0.78, a_{N}=1.3 \mathrm{~mm}$ のとき $C=0.59$ となった. また, ある流体の 粒子が上部水槽から落下して下部水槽の水面に達するまでの落下時間 $T$ は式(2)を用いて 


$$
T=\frac{\sqrt{2 g h+u_{N}^{2}}-u_{N}}{g}
$$

で与えられる. このようにして求めた落下時間 $T$ と, そのときに発生している水膜振動の振動数 $f$ との積

$$
S=T f
$$

は水膜が落下する間の振動回数を表す.

既報 ${ }^{(21)}$ によれば, 落下高さ $h$ あるいは上部水槽内の水位 $d$ が大きいと, より高次の振動モードが発生しやすい. 水膜が下部水槽に落下したときのエネルギーは水膜初速度 $u_{N}$ と落下高さ $h$ にって

$$
H=h+u_{N}^{2} /(2 g)
$$

で表され， $u_{N}$ は $d$ とともに大きくなることを考慮すれば，大きなエネルギーをもつ水膜では高次の振動モード が発生することを意味する. 図 3 は $h, d$ を変えて実験を行った結果を $H$ に対する $S$ の值で整理したものである. 小さい ○印および ○印は大きな印よりも現れる頻度が低いことを示しており， $H$ が増加すると $S$ も増加して いる（高次モードが現れている）ことが確認できる. なお，右上の 印は屋外の水膜振動を測定した結果であ り（図 4), 実験装置に比べて水膜の両側に板はなく水膜の両側で水膜前後の空間はつながっているが，水膜は幅 が $4 \mathrm{~m}$ 以上あり水膜背後では圧力変動が測定できた（図 5). 図 3 より, 実験を行った範囲については, 屋外の水

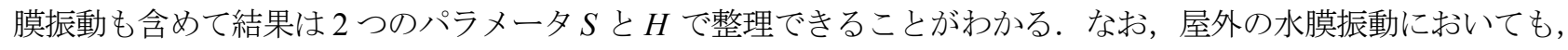
水膜下端の変位が最大となる（最も前に振り切れる）とき水膜背後の圧力は最大となり, 逆に水膜下端の変位が 最小となるとき水膜背後の圧力は最小となった.

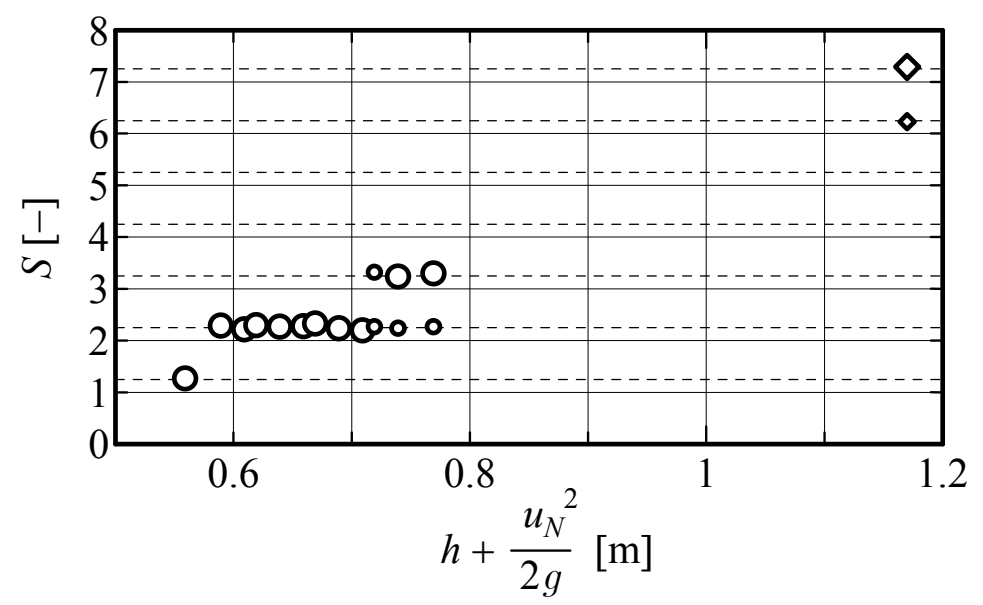

Fig.3 Effects of falling height $h$ and initial velocity $u_{N}$ on $S$ $(\bigcirc, \diamond$ : observed more frequently; $, \diamond:$ observed less frequently; $\bigcirc:$ Fig.1, $\diamond:$ Fig.4)

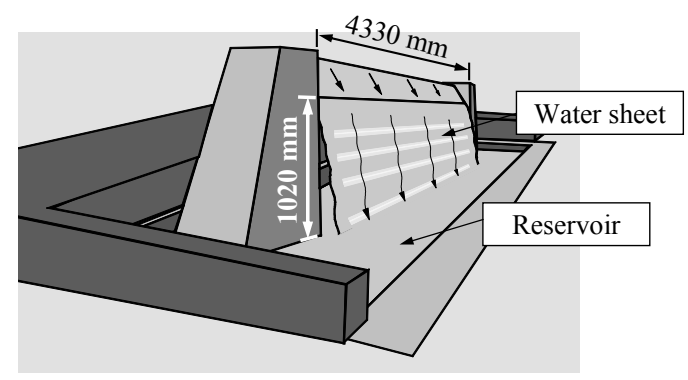

(a) Over view

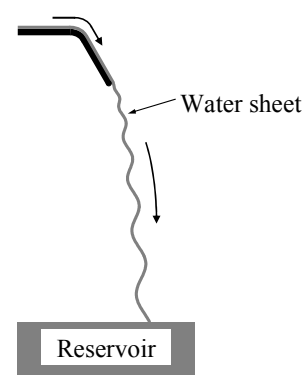

(b) Side view

Fig.4 Ornamental waterfall 


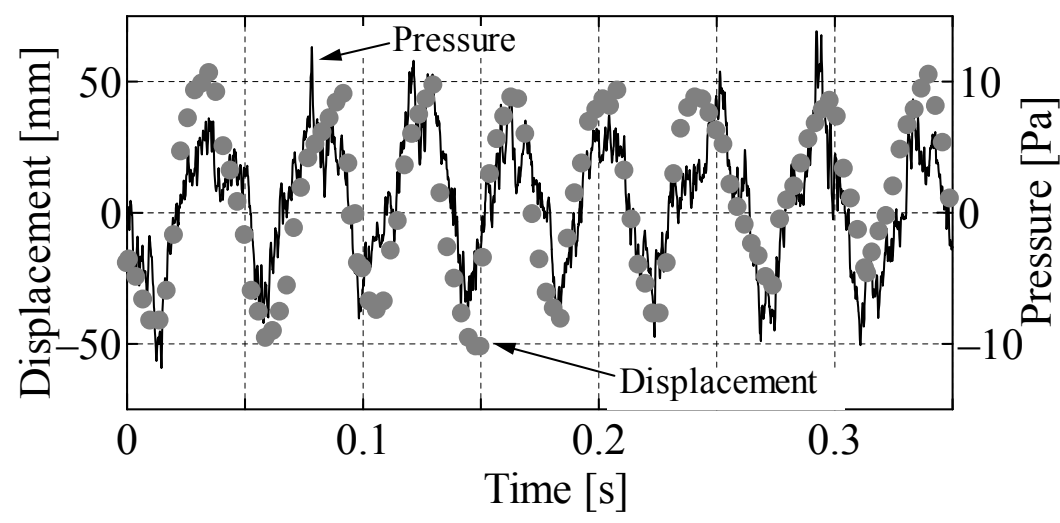

Fig.5 The relation between pressure variation behind the water sheet and the bottom displacement of a water sheet measured in Fig. 4

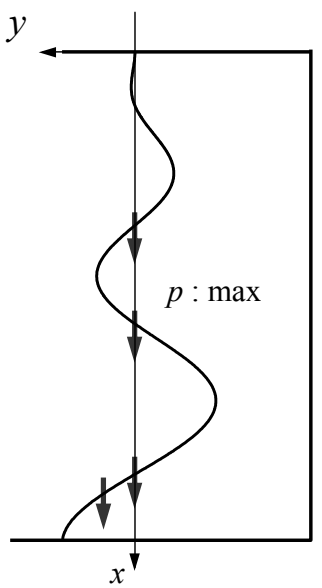

(a) When $p$ is maximum

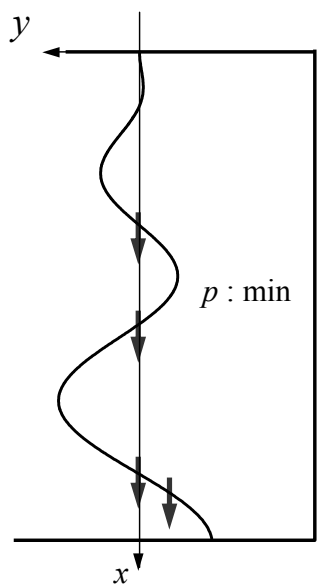

(b) When $p$ is minimum

Fig.6 Squeeze action ( $p$ :pressure behind a water sheet)

図 6 は，振動している落下水膜の最下部が最も左および右に振れたときの様子を示したものである. 図中の矢 印は水膜を構成する水の動きを表している. 図 6(a)で示す水膜最下部が最も左に振れたとき，水膜は落下してい るので水膜背後の空間は押し潰されることになり空気圧力は最大になり, 逆に図 6(b)で示寸水膜最下部が最も右 に振れたとき, 水膜の落下運動により水膜背後の空間は引き伸ばされることになり, 空気圧力は最小になると考 えられる.

\section{4. 解 析}

\section{$4 \cdot 1$ 運動方程式}

図 2 および図 5 の実験結果において水膜の変位に応じて大きく圧力が変動していることから, 水膜の押し潰し により起こる圧力変動 $\Delta p$ は水面での水膜変位 $\eta(h, t)$ に比例していると仮定する. 本報で提案する解析モデルは, 閉空間内の圧力変動 $\Delta p$ の決定方法を除けば前報 ${ }^{21)}$ と同様である. まず，水膜の変位は幅方向（図 1(a)の $z$ 軸方 向）に一様であるとする. さらに，水膜が薄いことを考慮して，水膜内における厚さ方向（図 $1(\mathrm{a})$ $㇒$ 軸方向） の圧力分布は一様であると仮定する. 水膜前面の空間の圧力は大気圧 $p_{0}$ で一定とし, 閉空間の圧力を $p_{0}+\Delta p$ と 表す. 閉空間の体積は音速に比べて十分に小さいため, 閉空間内の圧力変動 $\Delta p$ は一様であるとする. 図 7 のよ うに水膜の微小体積 $d x$ に作用する鉛直方向および氷平方向の力を考慮すると, 水膜の運動方程式は次式のように なる(21). 


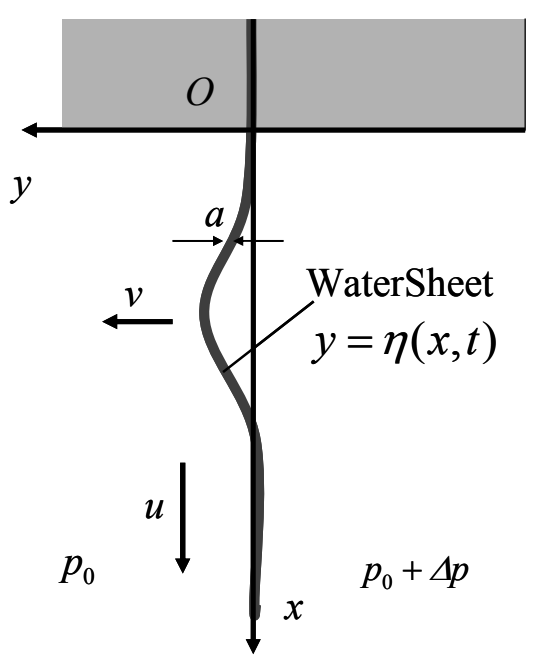

(a) Water sheet displacement and pressure variation

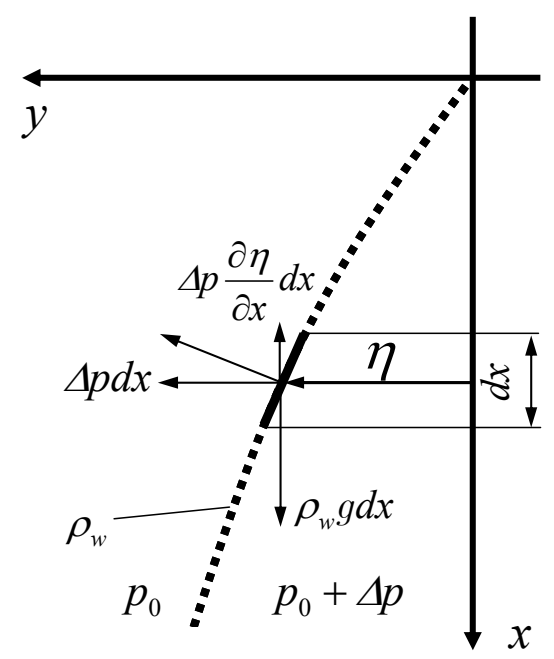

(b) Horizontal and vertical components of forces acting on a small element $d x$ of a water sheet

Fig.7 Analytical model

$$
\frac{\partial u}{\partial t}+u \frac{\partial u}{\partial x}=g-\frac{\Delta p}{\rho_{w} a} \frac{\partial \eta}{\partial x}, \frac{\partial v}{\partial t}+u \frac{\partial v}{\partial x}=\frac{\Delta p}{\rho_{w} a}
$$

ここに, $u$ および $v$ は水膜の $x$ 方向および $y$ 方向の速度, $\eta(x, t)$ は水膜の $y$ 方向変位, $\rho_{w}$ は水の密度, $a(x, t)$ は 水膜の厚さである. $v$ は $\eta(x, t)$ および $u$ を用いて

$$
v=\frac{\partial \eta}{\partial t}+u \frac{\partial \eta}{\partial x}
$$

と表すことができる. $x=0$ における境界条件は次式で与えられる.

$$
u=u_{N}, \quad v=0, \eta=0
$$

また，水の供給量は一定であるため，連続の式より次式が成り立つ.

$$
a u=a_{N} u_{N}=q_{N}=\text { const. }
$$

ここに， $a_{N}$ は水膜の初期厚さである.

これまでに，圧力変動 $\Delta p$ を決定するために閉空間の断熱変化および等温変化をはじめとしてさまざまなモデ ルが提案されているが(12),(13),(15),(16)，図6のような押し潰し作用を考慮したモデルは見当たらないようである. 本 報では押し潰し作用を仮定して，微小体積 $d x$ により生じる圧力変動を

$$
d p=\beta u \frac{\partial \eta}{\partial x} d x
$$

とする. ここに， $\beta$ は押し潰し作用の強さを表す正のパラメータである. 閉空間内の圧力変動は上記の $d p$ を落 下高さ $x=0 \sim h$ で積分した值

$$
\Delta p=\beta \int_{0}^{h} u \frac{\partial \eta}{\partial x} d x
$$

となる。

つぎに, 運動方程式を線形化するために, 水膜の速度 $u$ および $v$, 変位 $\eta$, 厚さ $a$, 圧力変動 $\Delta p$ を次式のよう に微小パラメータ $\varepsilon$ を用いて級数の形で表す. 


$$
\left.\begin{array}{lr}
u=u_{0}(x)+\varepsilon u_{1}(x, t)+\cdots \\
v= & \varepsilon v_{1}(x, t)+\cdots \\
\eta= & \varepsilon \eta_{1}(x, t)+\cdots \\
a=a_{0}(x)+\varepsilon a_{1}(x, t)+\cdots \\
\Delta p= & \varepsilon p_{1}(t)+\cdots
\end{array}\right\}
$$

ここに, 添え字 0 は平衡状態における量, 添え字 1 は変動量を表す. 式(12)を式(6)の第 1 式に代入すると, $x$ 方 向速度 $u$ について $\varepsilon^{0}$ および $\varepsilon^{1}$ の項から以下の式を得る.

$$
u_{0}=\sqrt{2 g x+u_{N}^{2}}, u_{1}=0
$$

$y$ 方向の水膜変位 $\eta$ については，式(6)の第 2 式，式(7)および式(12)より次式を得る.

$$
\frac{\partial^{2} \eta_{1}}{\partial t^{2}}+2 u_{0} \frac{\partial^{2} \eta_{1}}{\partial x \partial t}+u_{0} \frac{d u_{0}}{d x} \frac{\partial \eta_{1}}{\partial x}+u_{0}^{2} \frac{\partial^{2} \eta_{1}}{\partial x^{2}}=\frac{p_{1} u_{0}}{\rho_{w} a_{N} u_{N}}
$$

式(13)の第 1 式を用いて変数 $x$ を $u_{0}$ に変換すると, 式(14)は次式となる.

$$
\frac{\partial^{2} \eta_{1}}{\partial t^{2}}+2 g \frac{\partial^{2} \eta_{1}}{\partial u_{0} \partial t}+g^{2} \frac{\partial^{2} \eta_{1}}{\partial u_{0}^{2}}=\frac{p_{1} u_{0}}{\rho_{w} a_{N} u_{N}}
$$

一方，式(12)を式(11)に代入して $\varepsilon^{1}$ の項について整理すると，次式を得る.

$$
p_{1}=\beta \int_{0}^{h} u_{0} \frac{\partial \eta_{1}}{\partial x} d x
$$

ここで，以下の無次元時間および無次元速度を導入する.

$$
\bar{t}=\frac{g}{u_{N}} t, \bar{u}_{0}=\frac{u_{0}(x)}{u_{N}}
$$

無次元化された落下時間 $\bar{T}$ は次式で与えられる.

$$
\bar{T}=\bar{u}_{h}-1
$$

ここに,

$$
\bar{u}_{h}=\frac{u_{0}(h)}{u_{N}}
$$

である。

式(16)および(17)を式(15)に代入すると，

$$
\frac{\partial^{2} \eta_{1}}{\partial \bar{t}^{2}}+2 \frac{\partial^{2} \eta_{1}}{\partial \bar{u}_{0} \partial \bar{t}}+\frac{\partial^{2} \eta_{1}}{\partial \bar{u}_{0}^{2}}=B \bar{u}_{0} \int_{1}^{\bar{u}_{h}} \bar{u}_{0} \frac{\partial \eta_{1}}{\partial \bar{u}_{0}} d \bar{u}_{0}
$$

となる.ここに， $B$ は $\beta$ を無次元化した值であり，次式で与えられる.

$$
B=\frac{\beta u_{N}^{3}}{\rho_{w} a_{N} g^{2}}
$$




\section{$4 \cdot 2$ 運動方程式の解}

運動方程式(20)の解は次式のようになる.

$$
\eta_{1}\left(\bar{u}_{0}, \bar{t}\right)=H\left(\bar{u}_{0}\right) e^{\bar{\lambda} \bar{t}}
$$

ここに， $\bar{\lambda}$ は境界条件によって決まる特性根であり， $H\left(\bar{u}_{0}\right)$ は次式で与えられる.

$$
\begin{aligned}
H\left(\bar{u}_{0}\right)= & \left(C_{1}+C_{2} \bar{u}_{0}\right) e^{-\bar{\lambda} \bar{u}_{0}}+\frac{2\left(\bar{\lambda} \bar{u}_{0}-2\right) B}{\bar{\lambda}^{3}\left\{B\left(1-\bar{u}_{h}^{2}\right)+2 \bar{\lambda}^{2}\right\}}\left[-e^{-\bar{\lambda}}\left\{C_{2}+\bar{\lambda}\left(C_{1}+C_{2}\right)+\bar{\lambda}^{2}\left(C_{1}+C_{2}\right)\right\}\right. \\
& \left.+e^{-\bar{\lambda} \bar{u}_{h}}\left\{C_{2}+\bar{\lambda}\left(C_{1}+\bar{u}_{h} C_{2}\right)+\bar{\lambda}^{2} \bar{u}_{h}\left(C_{1}+\bar{u}_{h} C_{2}\right)\right\}\right]
\end{aligned}
$$

式(23)中の $C_{1}$ および $C_{2}$ は初期条件および境界条件によって決まる定数である. 式(8)の境界条件は $\bar{u}_{0}=1$ における $H\left(\bar{u}_{0}\right)$ の境界条件

$$
H(1)=0, \frac{d H}{d \bar{u}_{0}}(1)=0
$$

に変換される. 式(23)および(24)より，特性方程式は次式となる.

$$
2 e^{\bar{\lambda} \bar{u}_{h}} \bar{\lambda}^{4}+B\left[e^{\bar{\lambda}_{\bar{u}_{h}}}\left\{6-\bar{\lambda}^{2}\left(\bar{u}_{h}^{2}+1\right)\right\}+2 e^{\bar{\lambda}}\left\{\bar{\lambda}\left(\bar{\lambda}^{2} \bar{u}_{h}-3\right)\left(\bar{u}_{h}-1\right)-\bar{\lambda}^{2}\left(\bar{u}_{h}^{2}-3 \bar{u}_{h}+1\right)-3\right\}\right]=0
$$

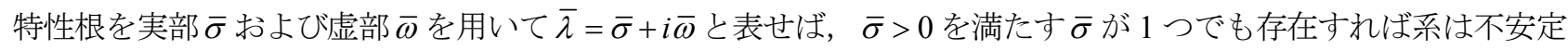

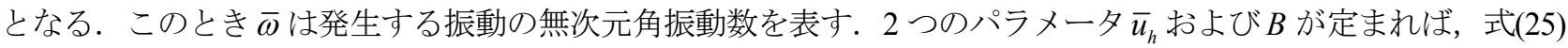

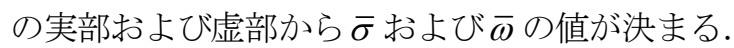

安定・不安定境界においては, 特性根 $\bar{\lambda}$ は純虚数 $\bar{\lambda}=i \bar{\omega}$ となる. これを式(25)に代入すると, 以下の式を得る.

$$
\left.\begin{array}{l}
\left.B^{*}=\frac{2 \alpha^{4}}{\left(\bar{u}_{h}-1\right)^{2}\left[-\alpha^{2}\left(\bar{u}_{h}^{2}+1\right)-6\left(\bar{u}_{h}-1\right)^{2}+2\left\{\left(3-\alpha^{2}\right)\left(\bar{u}_{h}-1\right)^{2}+\alpha^{2} \bar{u}_{h}\right\} \cos \alpha+2 \alpha\left\{\alpha^{2} \bar{u}_{h}+3\left(\bar{u}_{h}-1\right)^{2}\right\} \sin \alpha\right]}\right\} \\
\cot \alpha=F\left(\bar{u}_{h}, \alpha\right)
\end{array}\right\}
$$

ここに， $B^{*}$ は安定・不安定境界における $B$ の值であり，関数 $F\left(\bar{u}_{h}, \alpha\right)$ は次式で与えられる.

$$
F\left(\bar{u}_{h}, \alpha\right)=-\frac{\alpha\left(\bar{u}_{h}-1\right)^{2}}{\alpha^{2} \bar{u}_{h}+3\left(\bar{u}_{h}-1\right)^{2}}+\frac{1}{\alpha}, \quad \alpha=\bar{\omega}\left(\bar{u}_{h}-1\right)
$$

安定・不安定境界においては， $\bar{u}_{h}$ が定まれば式(26)の第 2 式から $\alpha$ が求まり, 式(26)の第 1 式から $B^{*}$ が求まる. $\alpha$ と の関係は

$$
S=\frac{\alpha}{2 \pi}=\frac{\bar{\omega}}{2 \pi}\left(\bar{u}_{h}-1\right)
$$

で与えられるので, 1 つのパラメータ $\bar{u}_{h}$ にって安定・不安定境界の $S$ および $B^{*}$ の值が求まる.この安定・不安 定境界における $S$ および $B^{*}$ の值を 1 次モードから順に $\left(S_{1}, B_{1}^{*}\right),\left(S_{2}, B_{2}^{*}\right),\left(S_{3}, B_{3}^{*}\right), \cdots$ と呼ぶ.

\section{5. 結果および考察}

\section{$5 \cdot 1$ 波数 $S$ およびモード選択のメカニズム}

図 8 は $\bar{u}_{h}=3.3$ の場合（図 2 の実験条件）における式(26)第 2 式の $\cot \alpha$ および $F\left(\bar{u}_{h}, \alpha\right)$ の值を $S(=\alpha /(2 \pi))$ の 関数として示したものである. $\cot \alpha$ と $F\left(\bar{u}_{h}, \alpha\right)$ の交点における $S$ の值が $S_{n}(n=1,2,3, \cdots)$ であり, そのとき式 $(26)$ 第 1 式で与えられる $B^{*}$ の值が $B_{n}^{*}(n=1,2,3, \cdots)$ となる. 図 8 を見ると, 横軸 $S$ の増加にともなって $F\left(\bar{u}_{h}, \alpha\right)$ の值 は急激にゼロに近づき， $S>0.5$ の領域では $F\left(\bar{u}_{h}, \alpha\right) \cong 0$ となっている. したがって， $S_{n}$ の值を与える式(26)の第 2 式は次式のように書ける. 


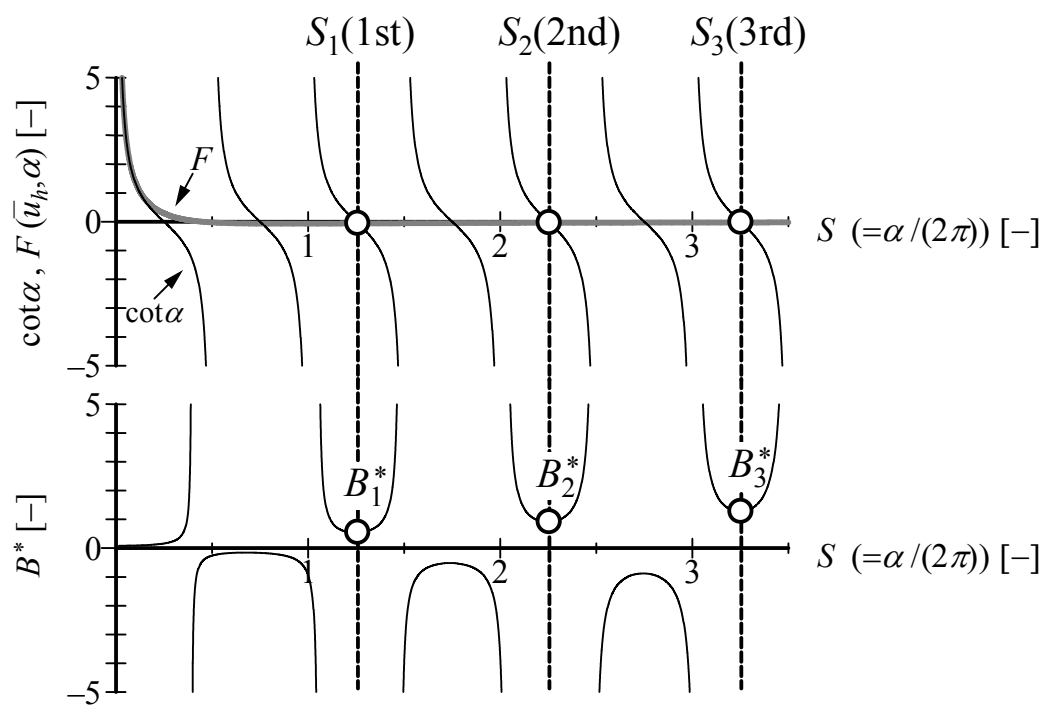

Fig.8 Calculated $S_{n}$ and $B_{n}^{*}\left(\bar{u}_{h}=3.3\right)$

Table 1 Calculated $S_{n}$ for the first through the fifth modes $\left(\bar{u}_{h}=3.3\right)$

\begin{tabular}{ccc}
\hline Mode & $S_{n}[-]$ & $B_{n}^{*}[-]$ \\
\hline 1st & 1.260 & 0.539 \\
2nd & 2.256 & 0.906 \\
3rd & 3.255 & 1.269 \\
4th & 4.254 & 1.630 \\
5th & 5.253 & 1.990 \\
\hline
\end{tabular}
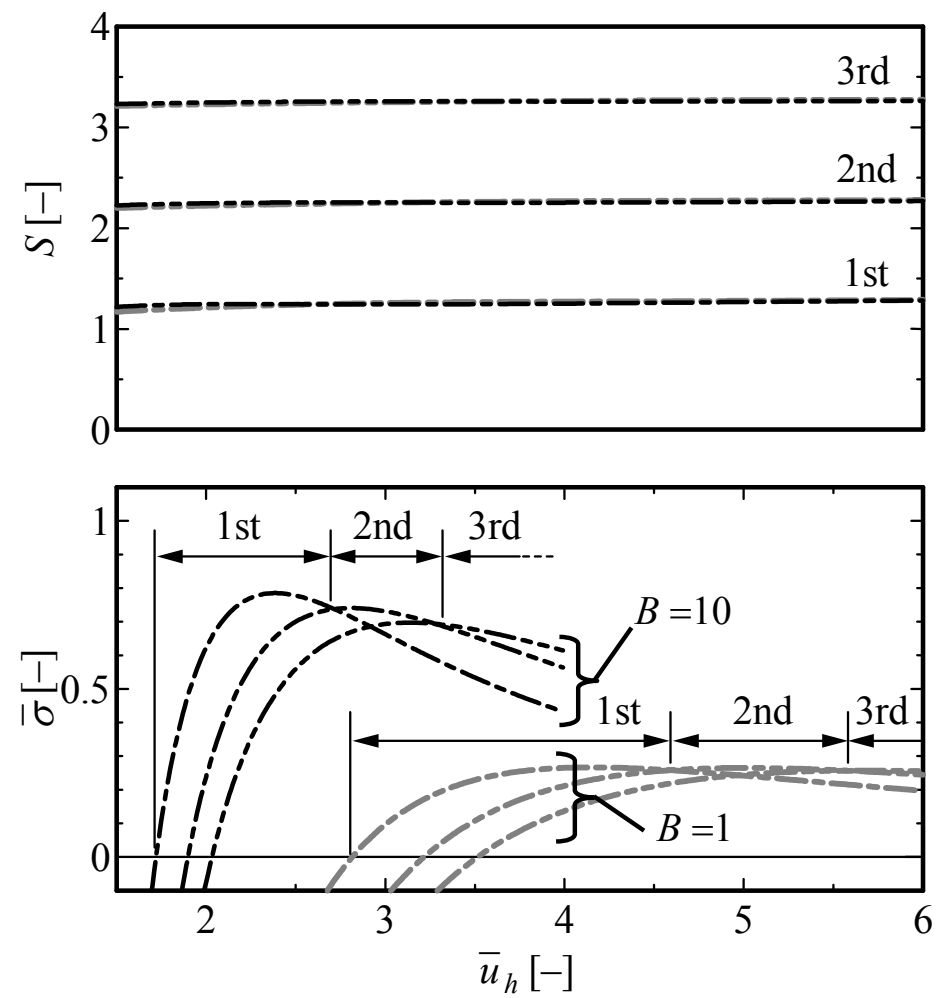

Fig.9 $S$ and $\bar{\sigma}$ versus $\bar{u}_{h}$ 


$$
\cot \alpha \cong 0
$$

式(29)より， $S_{n}$ の近似值として次式を得る.

$$
S_{n}=\frac{\alpha}{2 \pi} \cong n \pm 0.25 \quad(n=1,2,3, \cdots)
$$

図 8 に示すように, $S_{n} \cong n+0.25$ においては $B^{*}>0$ であるが, $S_{n} \cong n-0.25$ においては $B^{*}<0$ であり, $\beta$ の定義 および式(21)より物理的に $B^{*}>0$ でなければならないことから,

$$
S_{n} \cong n+0.25
$$

の特性根のみが意味をもつ。このように，Schwartz が導いた式を本報のモデルから理論的に得ることができる. 表 1 は式(26)より求められた $S_{n}$ の值を 1 次モードから 5 次モードまで示したものであり，式(31)が成り立つてい ることがわかる．図3 の破線は式(31)で与えられる $S_{n}$ の近似值を示したものである. 実験結果は破線上に分布し ていることから， $S_{n}$ の近似值は実験結果とよく一致していることが確認できる.

さらに，不安定領域における $S$ の值について考える. 図 9 は， $S$ および $\bar{\sigma}$ の值を $\bar{u}_{h}$ の関数として示したもので ある. 実験における $B$ の值の同定は困難であるので， $B=1$ （灰色）および $B=10$ （黒色）の $2 つ の$ 解析結果を 示している. 図 9 に示すように，不安定領域における $S$ の值は，式(31)で求められた安定・不安定境界における 值 $S_{n}$ から殆ど変化しない. したがって，不安定領域における $S$ の值も近似的に式(31)で表される.

このように，本報のモデルを用いると式(31)を理論的に求めることができ，安定・不安定境界における $S_{n}$ が「整 数值 $+0.25 」$ 」近い值となることを説明することができる.さらに，不安定領域における $S$ が安定・不安定境界 における $S_{n}$ とほぼ一致することを考慮すれば，不安定領域における $S$ も上記の值となることが示せる．したがっ て，図 3 の実験結果が破線上に分布することを説明することができる.

つぎに，モード選択のメカニズムについて考察する. 上述のように，1つの実験条件であっても初期条件によ って異なる次数の振動モードが発生しうる.これは，1つのパラメータにおいて複数の振動モードが同時に不安 定になることを意味している.さらに，図 3 の実験結果から落下高さ $h$ が大きくなると高次の振動モードが発生 しやすいことがわかる. これは， $h$ が増加すると（無次元速度 $\bar{u}_{h}$ が増加すると）高次の振動モードの不安定度 $\bar{\sigma}$ の值が高くなることを示唆している. 図 9 を見ると， $B=1$ および10のいずれにおいても， $\bar{u}_{h}$ が増加すると（落 下高さ $h$ が増加すると）複数のモードが不安定となることがわかる．また， $\bar{u}_{h}$ が増加するにつれて， 大となる振動モードが 1 次 $\rightarrow 2$ 次 $\rightarrow 3$ 次 $\rightarrow \cdots$ とより高次側に遷移している. これは図 3 の実験結果と定性的に 一致する.

\section{$5 \cdot 2$ エネルギーの流れ}

最後に，振動の原因について考察するために，運動方程式(6)をもとにエネルギーの流れについて述べる．1 周 期 $\tau$ の間に閉空間から水膜に作用する水平方向の力によってなされる仕事量は次式で与えられる.

$$
W_{y}=\int_{0}^{\tau} \int_{0}^{h} p_{1} v_{1} d x d t
$$

式(12)を式(6)の第 2 式に代入して $\varepsilon^{1}$ のオーダーの項について整理すると, 次式が得られる.

$$
p_{1}=\rho_{w} a_{0}\left(\frac{\partial v_{1}}{\partial t}+u_{0} \frac{\partial v_{1}}{\partial x}\right)
$$

式(33)を式(32)に代入すると，次式が得られる.

$$
W_{y}=\int_{0}^{\tau} \int_{0}^{h} \rho_{w} a_{0}\left(\frac{\partial v_{1}}{\partial t}+u_{0} \frac{\partial v_{1}}{\partial x}\right) v_{1} d x d t=\int_{0}^{\tau} \int_{0}^{h} \rho_{w} a_{0} v_{1} \frac{\partial v_{1}}{\partial t} d x d t+\int_{0}^{\tau} \int_{0}^{h} \rho_{w} a_{0} u_{0} v_{1} \frac{\partial v_{1}}{\partial x} d x d t
$$

式(34)の最右辺第 1 項は次式のように変形できる. 


$$
\int_{0}^{\tau} \int_{0}^{h} \rho_{w} a_{0} v_{1} \frac{\partial v_{1}}{\partial t} d x d t=\int_{0}^{h} \rho_{w} a_{0}\left[\frac{1}{2} v_{1}^{2}\right]_{0}^{\tau} d x=\left[\int_{0}^{h} \frac{1}{2} \rho_{w} a_{0} v_{1}^{2} d x\right]_{0}^{\tau}=E_{y}(\tau)-E_{y}(0)=\Delta E_{y}
$$

ここに,

$$
E_{y}(t)=\int_{0}^{h} \frac{1}{2} \rho_{w} a_{0} v_{1}^{2} d x, \Delta E_{y}=E_{y}(\tau)-E_{y}(0)
$$

である. $E_{y}(t)$ は水膜の水平方向速度に基づく運動エネルギーを示しており, $\Delta E_{y}$ はその 1 周期間の増分を表し ている．式(9)を考慮すると，式(34)の最右辺第 2 項は次式のように書ける.

$$
\int_{0}^{\tau} \int_{0}^{h} \rho_{w} a_{0} u_{0} v_{1} \frac{\partial v_{1}}{\partial x} d x d t=\int_{0}^{\tau} \rho_{w} q_{N}\left(\int_{0}^{h} v_{1} \frac{\partial v_{1}}{\partial x} d x\right) d t=\int_{0}^{\tau} \rho_{w} q_{N}\left[\frac{1}{2} v_{1}^{2}\right]_{0}^{h} d t=\int_{0}^{\tau} \frac{1}{2} \rho_{w} q_{N} v_{1 h}^{2} d t=E_{\text {yout }}
$$

ここに,

$$
v_{1 h}=v_{1}(h, t), \quad E_{\text {yout }}=\int_{0}^{\tau} \frac{1}{2} \rho_{w} q_{N} v_{1 h}^{2} d t
$$

であり, $E_{\text {yout }}$ は $x=h$ における水平方向速度によって 1 周期の間に系から流れ出る運動エネルギーを表している. 式(35)および(37)を式(34)に代入すると，次式を得る.

$$
W_{y}=\Delta E_{y}+E_{\text {yout }}
$$

この式は, 閉空間から水膜になされる仕事の一部が $E_{\text {yout }}$ として流れ出て, 残りが運動エネルギーの増分 $\Delta E_{y}$ とな ることを示している.

一方，水膜から閉空間に作用する鋁直方向の力が 1 周期にな寸仕事は次式で与えられる.

$$
W_{x}=\int_{0}^{\tau} \int_{0}^{h} p_{1} u_{0} \frac{\partial \eta_{1}}{\partial x} d x d t
$$

式(7), (12), (32)および(40)より，次式を得る.

$$
\begin{gathered}
W_{x}-W_{y}=\int_{0}^{\tau} \int_{0}^{h} p_{1} u_{0} \frac{\partial \eta_{1}}{\partial x} d x d t-\int_{0}^{\tau} \int_{0}^{h} p_{1} v_{1} d x d t=-\int_{0}^{\tau} \int_{0}^{h} p_{1} \frac{\partial \eta_{1}}{\partial t} d x d t=-\int_{0}^{\tau} p_{1} \frac{d}{d t}\left(\int_{0}^{h} \eta_{1} d x\right) d t \\
=-\int_{0}^{\tau} p_{1} \frac{d V_{1}}{d t} d t=-\int_{V_{1}(0)}^{V_{1}(\tau)} p_{1} d V_{1}=W_{V}
\end{gathered}
$$

ここに,

$$
V_{1}(t)=\int_{0}^{h} \eta_{1} d x, \quad W_{V}=-\int_{V_{1}(0)}^{V_{1}(\tau)} p_{1} d V_{1}
$$

である. $V_{1}(t)$ は水膜変位 $\eta_{1}$ に起因する閉空間の体積変化を表し, $W_{V}$ は体積変化のために必要な仕事を表す. 式(39)および(41)より，エネルギーの流れを表す次式を得る.

$$
W_{x}-W_{V}-E_{\text {yout }}=\Delta E_{y}
$$

上式は, 水膜が落下寸ることにより閉空間内になされる仕事 $W_{x}$ から体積変化のための仕事 $W_{V}$ および $x=h$ におい て流出寸る運動エネルギー $E_{\text {yout }}$ が失われ, 残りが運動エネルギーの増分 $\Delta E_{y}$ となることを意味している. $\Delta E_{y}>0$ のとき系は不安定であり， $\Delta E_{y}<0$ であれば安定となる. 図 10 は，このようなエネルギーの流れを示したもので ある.

計算にあたり， $W_{x}$ を次式のように無次元化する. 


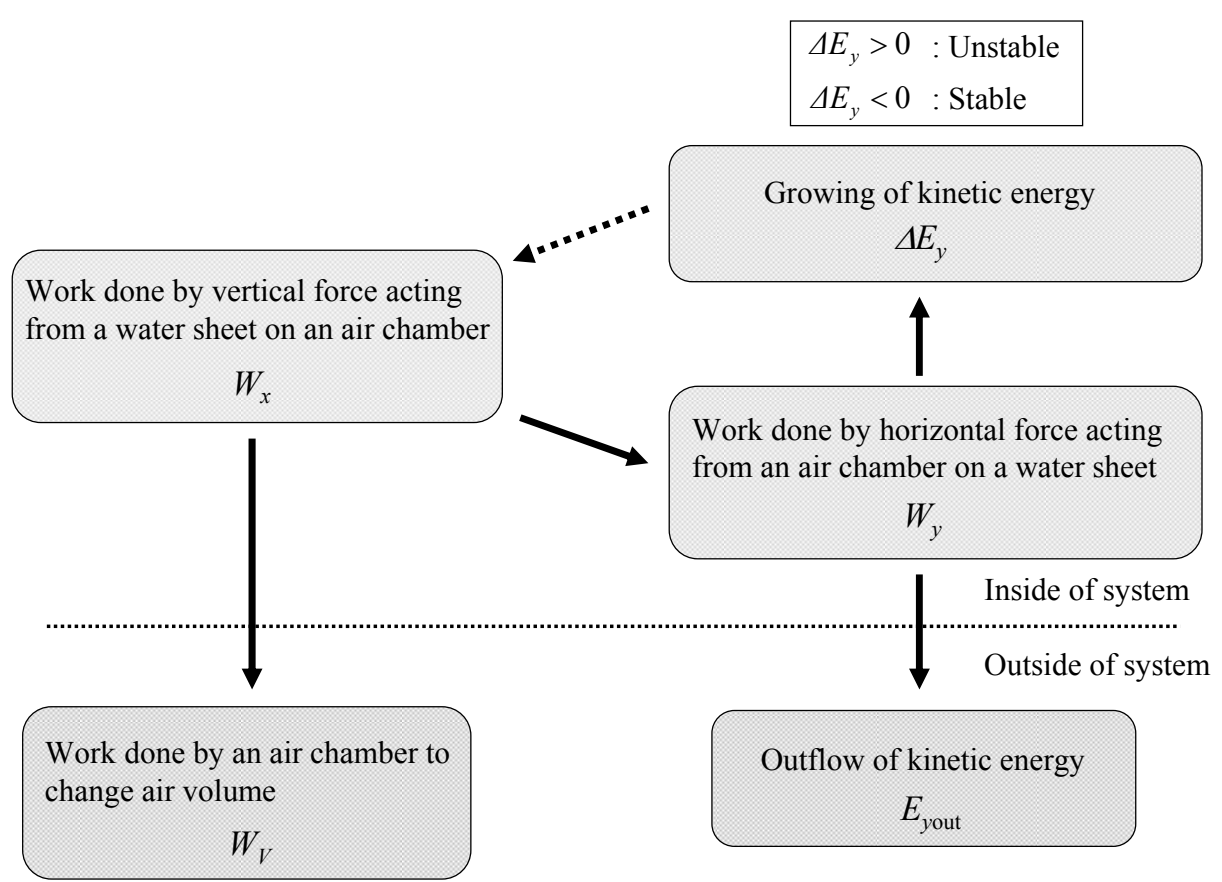

Fig.10 Schematic of the energy flow

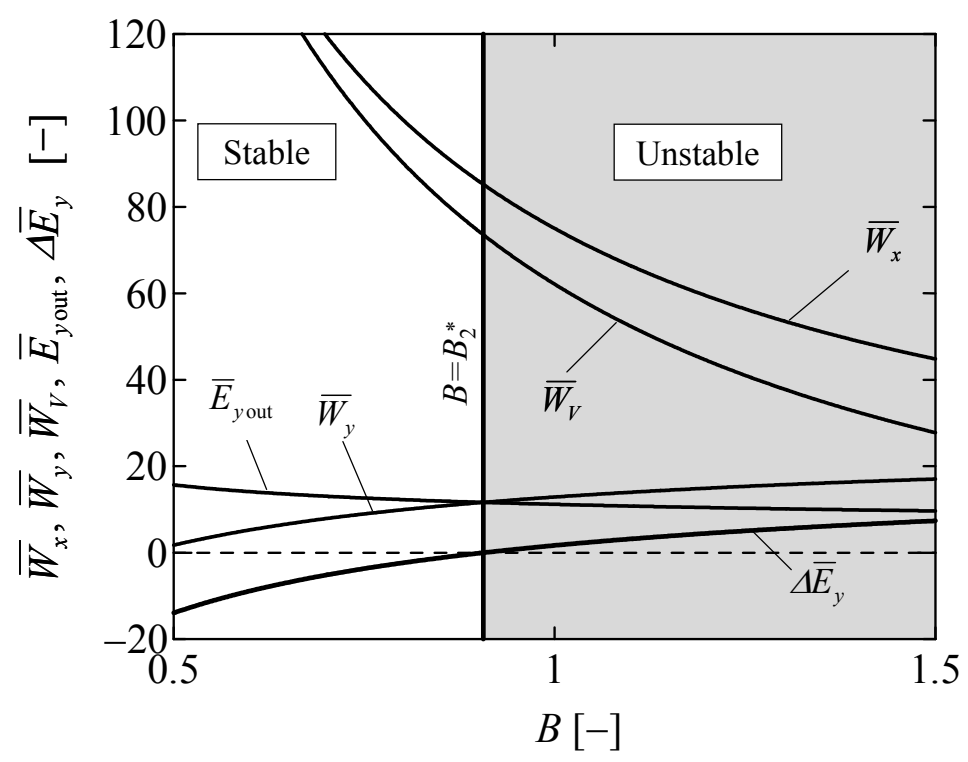

Fig.11 $\bar{W}_{x}, \bar{W}_{y}, \bar{W}_{V}, \bar{E}_{y \text { out }}$ and $\Delta \bar{E}_{y}$ (2nd mode for $\bar{u}_{h}=3.3$ )

$$
\bar{W}_{x}=\frac{W_{x}}{\rho_{w} a_{N} g C_{1}^{2}}=\frac{\int_{0}^{\tau} \int_{0}^{h} p_{1} u_{0} \frac{\partial \eta_{1}}{\partial x} d x d t}{\rho_{w} a_{N} g C_{1}^{2}}
$$

$W_{y}, W_{V}, E_{y \text { out }}$ および $\Delta E_{y}$ についても同様に無次元量 $\bar{W}_{y}, \bar{W}_{V}, \bar{E}_{\text {yout }}$ および $\Delta \bar{E}_{y}$ に変換する. 図 11 は, $\bar{u}_{h}=3.3$ の 2 次モードにおける $\bar{W}_{x}, \bar{W}_{y}, \bar{W}_{V}, \bar{E}_{y \text { out }}$ および $\Delta \bar{E}_{y}$ を $B$ の関数として示したものである. 図中には安定・不安定境界に おける $B$ の值 $B_{2}^{*}$ も併せて示している. 図 11 より， $\Delta \bar{E}_{y}>0$ のとき系が不安定であり， $\Delta \bar{E}_{y}<0$ のとき安定である ことが確認できる. 


\section{6. 結}

落下水膜振動における水膜変位と水膜背後圧力の関係を実験的に調べた結果，水膜振動の発生に水膜背後の空 気に対する水膜の押し潰し作用が影響していると考えることができるので，この押し潰し作用を仮定して解析モ デルを導出した。この解析モデルを理論解析することにより得られた振動モードは実験結果とよく一致した. 1 つの条件下で 2 つら 3 つの複数のモードの水膜振動が現れるが，その中のいずれかのモードが現れる「頻度」 が高い. どのモードが現れやすいかについても，提案した解析モデルにより説明できた．最後に，エネルギーの 流れに関する考察を行い，落下水膜から閉空間に作用する鉛直方向の力がなす仕事によって振動の原因の 1 つが 説明できることを示した.

最後に, 本報の実験には元 埼玉大学大学院 三浦秀一氏および船木圭太氏の助力を得たことを記して謝意を表 する.

\section{文献}

(1) Rayleigh, L., "On the Instability of Jets”, Proceedings of the London Mathematical Society, Vol.10, (1878), pp.4-13.

(2) Rayleigh, L., Theory of Sound, 2nd ed, Dover, (1896), pp.374-384.

(3) Squire, H. B., "Investigation of the Instability of a Moving Liquid Film", British Journal of Applied Physics, Vol.4, (1953), pp.167-169.

(4) York, J. L., Stubbs, H. E., Tek, M. R., “The Mechanism of Disintegration of Liquid Sheets”, Transactions of the ASME, Vol.75, (1953), pp.1279-1286.

(5) Hagarty, W. W., Shea, J. F., “A Study of the Stability of Plane Fluid Sheets”, Journal of Applied Mechanics, Vol.22, (1955), pp.509-514.

(6) Clark, C. J., Dombrowski, N., "Aerodynamic Instability and Disintegration of Inviscid Liquid Sheets", Proceedings of the Royal Society of London A., Vol.329, (1972), pp.467-478.

(7) Lin, S. P., "Stability of a Viscous Liquid Curtain”, Journal of Fluid Mechanics, Vol.104, (1981), pp.111-118.

(8) De Luca, L., Costa, M., “Instability of a Spatially Developing Liquid Sheet”, Journal of Fluid Mechanics, Vol.331, (1997), pp.127-144.

(9) Söderberg , L. D., "Absolute and Convective Instability of a Relaxational Plane Liquid Jet”, Journal of Fluid Mechanics, Vol.493, (2003), pp.89-119.

(10) Naudascher, E., Rockwell, D., Flow-Induced Vibrations, Dover, (2005), pp.142-144.

(11) Schwartz, H. I., "Nappe Oscillation”, Journal of the Hydraulics Division, Vol.90, (1964), pp.129-143.

(12) Treiber, B., "Theoretical Study of Nappe Oscillation”, IUTAM/IAHR Symposium, (1972), pp.34-46.

(13) Kolkman, P. A., "Instability of a Vertical Water-Curtain Closing an Air-Chamber", IUTAM/IAHR Symposium, (1972), pp.17-33.

(14) 大久保精二, 角哲也,”鉛直落下水膜の振動特性”, 土木学会第 43 回年次学術講演会, (1988).

(15) Casperson, L. W., “Fluttering Fountains”, Journal of Sound and Vibration, Vol.162, (1993), pp.251-262.

(16) Kyotoh, H., Nakamura, R., Baruah, P. J, "Incipient Oscillations of a Sheet of Falling Water and the Instability Mechanisms", Journal of Hydroscience and Hydraulic Engineering, Vol.20, No.1, (2002), pp.77-93.

(17) Petrikat, K. "Vibration Tests on Weirs and Bottom Gates", Water Power, Vol.10, (1958), pp.52-57, 99-104.

(18) 本間仁, 荻原国宏, “フラップゲートの振動についての理論解析”, 土木学会論文報告集, No.238, (1975), pp.43-53.

(19) Ogihara, K., "Unstable Condition of Self-Excited Oscillation of Flap Gate”, International Association for Hydraulic Research, 21st Congress, (1985), pp.621-626.

(20) 角哲也, 大久保精二, “フラップゲート越流水膜の振動特性”, 土木学会第 43 回年次学術講演会, (1988), pp.456-457.

(21) 佐藤勇一, 三浦秀一, 長嶺拓夫, 森井茂樹, 大久保精二, “落下水膜の挙動に関する研究”, 日本機械学会論文集 C 編, Vol.71, No.709,(2005), pp.2685-2692. 